\title{
Perusal of Mbl2 Gene -Susceptibility to Tuberculosis in Different Indian Populations
}

\author{
C.V. Umesh ${ }^{1,5}$, A.M. Jamsheer ${ }^{2,5}$, Prasad M Alex ${ }^{3}$, P K Krishnan Namboori ${ }^{4 *}$ \\ ${ }^{1}$ Department of Chemistry, MES College - Nedumkandam-685553, Kerala, India. \\ ${ }^{2}$ Department of Chemistry, MES Mampad College - Mampad-676542, Kerala, India. \\ ${ }^{3}$ Department of Chemistry, Marthoma College - Chungathara-679334, Kerala, India. \\ ${ }^{4}$ Computational Engineering and Networking - AMRITA Vishwa Vidyapeetham, Coimbatore-641112, India. \\ ${ }^{5}$ Research and Development centre, Bharathiar University, Coimbatore-641046, India.
}

\begin{tabular}{l} 
ARTICLE INFO \\
\hline Article history: \\
Received on: $29 / 05 / 2015$ \\
Revised on: $11 / 07 / 2015$ \\
Accepted on: $05 / 08 / 2015$ \\
Available online: $27 / 09 / 2015$ \\
\hline Key words: \\
MBL2 Gene, Tuberculosis, \\
Sift, Damaging, SNP. \\
\hline
\end{tabular}

\section{INTRODUCTION}

The tuberculosis (TB) is a pandemic disease throughout the world even now, which is caused by Mycobacterium tuberculosis. In India, TB is a major concern and the administration is trying to make India free from the disease as a part of the 'post-2015 global TB strategy', implemented by World Health Organization (WHO, 2014). It has been observed that the mannose-binding lectin (MBL) plays a major role in the susceptibility of the disease. The deficiency of MBL has been identified as incriminating the risk of various infections viral, bacterial, and fungal (Capparelli et al., 2009).

The MBL serum production is controlled by the MBL2 gene. The gene carries four alleles, $\mathrm{A}, \mathrm{B}, \mathrm{C}$ and $\mathrm{D}$ and four variants, $\mathrm{H}, \mathrm{L}, \mathrm{X}$ and $\mathrm{Y}$. It has been observed that the haplotype pair $H Y A / H Y A$ of the gene grant to the resistance against pulmonary tuberculosis, whereas $L Y B / L Y D$ favors the disease (Fernando et al.., 2006) (Elango and Soojin., 2011). SNPS within

\footnotetext{
* Corresponding Author

Dr. P K Krishnan Namboori, Computational Chemistry Research Group, Computational Engineering and Networking - AMRITA Vishwa Vidyapeetham, Coimbatore-641112, India.

Phone:04222685000,Email:n_krishnan@cb.amrita.edu
}

the candidate genes have been treated to characterize responsiveness of a person to a particular disease (Guerra and $\mathrm{Yu}$, 2006).

The SNPs have been identified as the major variant corresponding to responsiveness of the disease. Out of various types of SNPs, the meSNPs are indicators of methylation possibility, while cisSNPs stand for mutation possibilities. Among SNPs, those pathogenic ones corresponding to amino acid variations are the deleterious SNPs, which stand for the genetic signature behind the mutation. The present study is on identification of proneness of TB and genetic signature behind susceptibility of microbial attack focusing on the MBL2 gene to tuberculosis.

\section{MATERIALS AND METHODS}

The gene population data has been obtained from the Indian Genome Variation database (IGVdb) (Indian Genome Variation Consortium., 2008). The CT, CC and TT genotype frequency variations within $\mathrm{C} / \mathrm{T}$ allelic variation have been compared through the 'coefficient of variation' values. The characterization of the mutation has been made with the help of HGMDb (The Human Gene Mutation Database., 2008). 
The SNPs present in the gene have been identified and classified into cisSNP, meSNP and transSNP based upon the position of SNPs with respect to $\mathrm{CpG}(-\mathrm{C}-$ phosphate $-\mathrm{G}-)$ Island observed by Database of $\mathrm{CpG}$ islands and Analytical Tool (DBCAT) (Graff et al., 1997). The deleterious SNPs have been identified with the help of SIFT (Sorting Intolerant From Tolerant) and Polyphene2 (Kumar et al., 2009) (Adzhubei et al., 2013). The SIFT compares the sequence while Polyphene2 compares the structure of the protein molecules produced from the gene (Namboori et al., 2011).

\section{RESULTS AND DISCUSSION}

The human MBL2 gene is located on chromosome 10 in the region 11.2-21.1(Safran et al., 2002).The SNP rs1800450 of MBL2 has been found in the 'coding exon1' having alleles $\mathrm{C}$ and $\mathrm{T}$ and is identified over fifty five different populations in India. Seven types of mutations have been reported for MBL2, in which four of them are Missense/Non sense and three of them are regulatory mutations (Table 1,2). The high value frequency is observed for the population IE-E-IP1 (Jharkhand) for the bases T and genotype CT, for DR-C-IP2 (Chattisgarh) population for genotype CC and for DR-S-LP4 (Karnataka) for genotype TT
(Indian Genome Variation Consortium., 2008).A total of 2246 SNPs have been identified for the gene, MBL2. Out of these, three pathogenic missense SNPs, rs1800450, rs1800451 and rs5030737have been chosen for analyzing the deleterious behavior. All the SNPs are identified as cisSNPs, and are the variables corresponding to mutability of the gene. The SIFT and Polyphene2 analyses support the SNPs as deleterious. Out of three MBL2 SNPs two SNPs showed $\mathrm{G} \rightarrow$ A nucleotide change and one $\mathrm{SNP} \mathrm{C} \rightarrow \mathrm{T}$. Damaging SNPs have score values less than or equal to 0.01 (Table 3).In Polyphene2 a score difference of 0.9 and above is considered to be probably damaging(Table 4). Hence these SNPs can be considered as the genetic signature behind susceptibility towards the attack of Mycobacterium Tuberculosis. In the Indian populations, only rs1800450 is observed. The coefficient variation (CV) frequency is very small for DR-S-IP4 (Kerala), while the maximum variation is found for DR-C-IP2 (Chhattisgarh) (Figure 1). Based on the above analysis, all the three SNPs of MBL2 have been identified as deleterious and markers of proneness of TB.

We conclude that rs 1800450 with a variation of Cytosine to Thymine could be the main target for Mannose-binding protein deficiency caused by the MBL2. This SNP can be considered as a genetic signature behind proneness of attack by Tuberculosis.

Table 1: Missense/nonsense Mutations.

\begin{tabular}{|c|c|c|c|}
\hline Accession no. & Codon Change & Amino acid change & Phenotype \\
\hline CM960957 & CGT-TGT & ARG-CYS & Mannose-binding protein deficiency \\
\hline CM920484 & GGC-GAC & GLY-ASP & Mannose-binding protein deficiency \\
\hline СM920485 & GGA-GAA & GLY-GLU & Mannose-binding protein deficiency \\
\hline CM068190 & CTG-CTC & LEU-LEU & Increased Serum Level \\
\hline
\end{tabular}

Table 2: Regulatory Mutations.

\begin{tabular}{|c|c|c|}
\hline Accession no. & Sequence & Phenotype \\
\hline CR952186 & $\begin{array}{l}\text { CAGAGAAAATGCTTACCCAGGCAAGCCTGT } \\
\text { (G-C)TAAAACACCAAGGGGAAGCAAACTCCAGTT }\end{array}$ & $\begin{array}{l}\text { Mannose-binding protein } \\
\text { deficiency }\end{array}$ \\
\hline CR952185 & $\begin{array}{l}\text { ATGCACGGTCCCATTTGTTCTCACTGCCAC } \\
\text { (G-C)GAAAGCATGTTTATAGTCTTCCAGCAGCAA }\end{array}$ & $\begin{array}{l}\text { Mannose-binding protein } \\
\text { deficiency }\end{array}$ \\
\hline CRO65614 & $\begin{array}{l}\text { GCACCCAGATTGTAGGACAGAGGGCATGCT } \\
\text { (C-T)GGTAAATATGTGTTCATTAACTGAGATTAA }\end{array}$ & $\begin{array}{l}\text { Mannose-binding protein } \\
\text { deficiency }\end{array}$ \\
\hline
\end{tabular}

Table 3: Sift Analysis.

\begin{tabular}{|c|c|c|c|c|c|}
\hline Sl. no. & SNP No. & Codon & Prediction & Score & Residue change \\
\hline 1 & rs 1800450 & GGC-GAC & Damaging & 0.01 & Gly-Asp \\
\hline 2 & rs 1800451 & GGA-GAA & Damaging & 0.00 & Gly-Glu \\
\hline 3 & rs5030737 & CGT-TGT & Damaging & 0.00 & Arg-Cys \\
\hline
\end{tabular}

Table 4: Poly Phen -2 Analysis.

\begin{tabular}{|c|c|c|c|c|}
\hline SNP & Prediction & Score & Sensitivity & Specificity \\
\hline rs 1800450 & Probably Damaging & 1.000 & 0.00 & 1.00 \\
\hline rs 1800451 & Probably Damaging & 0.994 & 0.69 & 0.97 \\
\hline rs5030737 & Probably Damaging & 1.000 & 0.00 & 1.00 \\
\hline
\end{tabular}


Coefficient of Variation

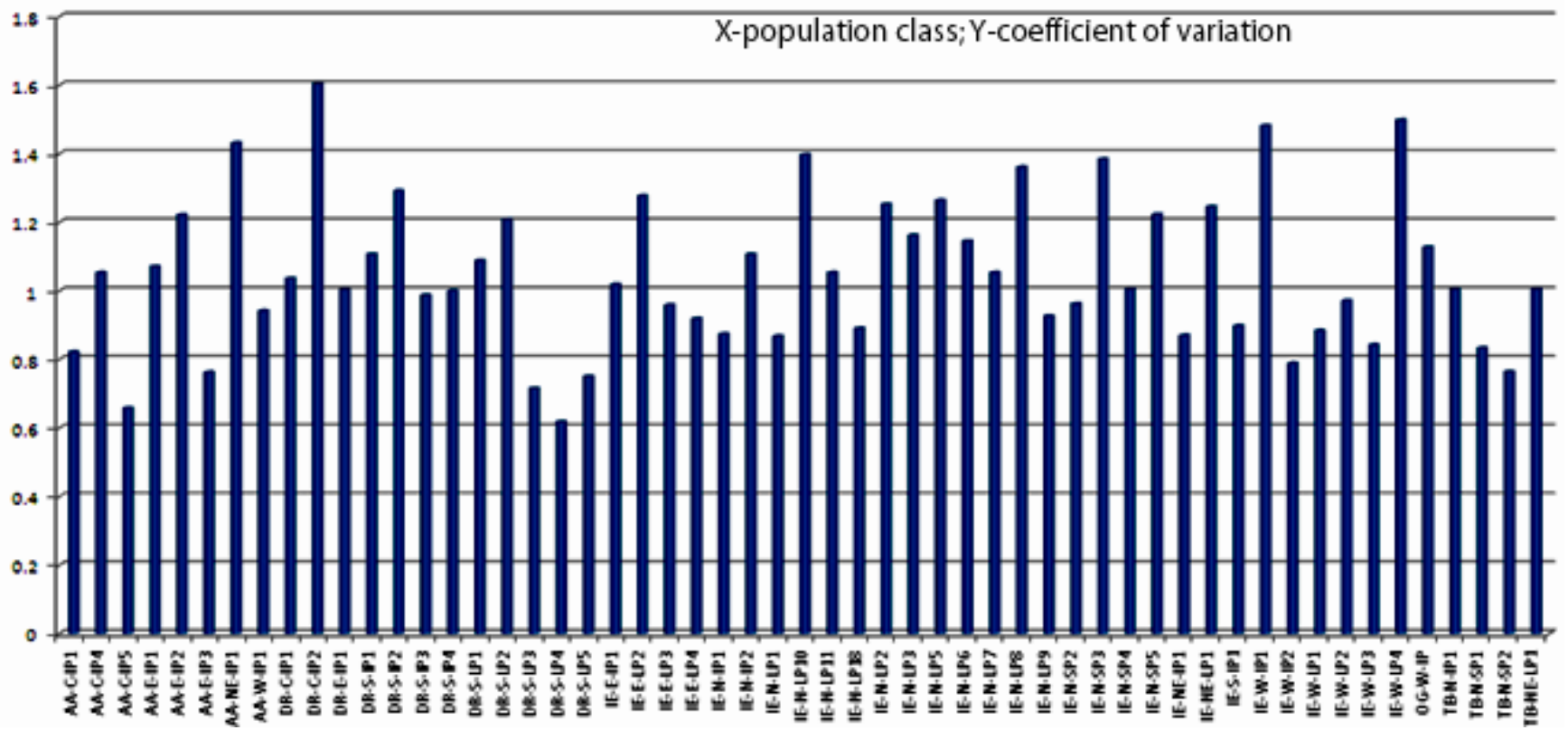

Fig. 1:Coefficient of variation in frequencies among different population

\section{CONCLUSION}

Mycobacterium Tuberculosis MBL2gene has been studied in this work by evaluating the influence of variation SNPs through computational methods. All the SNPs of MBL2, rs1800450, rs1800451andrs5030737, have been identified as deleterious to TB. In India rs 1800450 SNP is commonly found in about fifty five different populations and has been categorized as damaging. It can be concluded that rs 1800450 is a genetic signature behind mannose-binding protein deficiency caused by the MBL2 gene. This SNP can be considered as the marker for susceptibility towards the attack of Tuberculosis.

\section{REFERENCES} Organization.

Global Tuberculosis Report 2014, WHO2014, World Health

Capparelli R, Iannaccone M, Palumbo D, Medaglia C, Moscariello E, Russo A, Iannelli D. Role played by human mannosebinding lectin polymorphisms in pulmonary tuberculosis. Journal of Infectious Diseases, 2009; 199(5): 666-672.

Fernando, Suran L, Warwick J. Britton. Genetic susceptibility to mycobacterial disease in humans. Immunology and cell biology, 2006; 84(2): 125-137.

Elango N, Soojin V. Y. Functional relevance of $\mathrm{CpG}$ island length for regulation of gene expression. Genetics, 2011; 187(4): 10771083 .

Indian Genome Variation Consortium.Genetic landscape of the people of India: a canvas for disease gene exploration. Journal of genetics, 2008; 87(1): 3-20.

Kumar Prateek, Steven Henikoff, Pauline C Ng. Predicting the effects of coding non-synonymous variants on protein function using the SIFT algorithm. Nature protocols, 2009; 4(7):1073-1081.
Adzhubei Ivan, Daniel M. Jordan, Shamil R. Sunyaev. Predicting functional effect of human missense mutations using PolyPhen-2.Current protocols in human genetics, 2013: 7-20.

StensonPD, Mort M, Ball EV, Howells K, Phillips AD, Thomas NS, Cooper DN. The Human Gene Mutation Database: 2008 update Genome Med., 2009; 1(1): 13.1-13.6.

Safran M, Solomon I, Shmueli O, Lapidot M, Shen-Orr S, Adato A, Lancet D. GeneCards ${ }^{\mathrm{TM}}$ 2002: towards a complete, object oriented, human gene compendium. Bioinformatics, 2002;18(11): 1542 1543.

Graff, Jeremy $\mathrm{R}$, et al. Mapping patterns of $\mathrm{CpG}$ island methylation in normal and neoplastic cells implicates both upstream and downstream regions inde novo methylation.Journal of Biological Chemistry, 1997; 272(35): 22322-22329.

Rudy Guerra, Zhaoxia Yu. 2006. Single Nucleotide Polymorphisms and Their Applications. In:

Wei Zhang,IlyaShmulevich, ed.Computational and statistical approaches to genomics. US:Springer 311-349.

Namboori PK., Vineeth KV, Rohith V, Hassan I, Sekhar L, Sekhar A, Nidheesh M. The ApoE gene of Alzheimer's disease (AD) Functional \& integrative genomics, 2011;11(4): 519-522.

\section{How to cite this article:}

Umesh C.V., Jamsheer A.M., Prasad M Alex, Krishnan Namboori P K. Potential of aqueous extract of hibiscus sabdariffa calyces as colouring agent in three paediatric oral pharmaceutical formulations. J App Pharm Sci, 2015; 5 (09): 097-099. 